なぜスポーツファーマシストはカードゲームを開発したか？

清水雅之

\title{
Why Did the Sports Pharmacists Create the Card Game?
}

\author{
Masayuki Shimizu \\ Midoriya Pharmacy; 4-8-10 Nakamizo, Shimada, Shizuoka 427-0043, Japan.
}

(Received August 11, 2021)

\begin{abstract}
Anti-doping (AD) education for athletes is mainly one-way and through passively attended lectures. As such, learning about prohibited substances and highly technical doping rules is often difficult for athletes. Therefore, having athletes passively attending lectures is not enough to prevent unintentional doping violations caused by medicines and supplements. Therefore, it is important for athletes to acquire knowledge about individual prohibited substances as well as active learning and practical knowledge about AD measures. "Doping Guardian" is an educational card game that has been developed to help prevent unintentional doping violations. Participants (pharmacists) of this game can learn how to use medicines and supplements from an $\mathrm{AD}$ perspective while simulating the life of an athlete. This presentation will provide an overview of this card game and how it has been used to date.
\end{abstract}

Key words_—anti-doping; sports pharmacist; doping guardian; card game

\section{はじめに}

現在，日本国内においては競技力向上を目的とし た意図的なドーピング防止とともに日本国内で発生 比率の多い疾患の治療に用いる医薬品や健康食品, サプリメントが原因による意図的ではないいわゆる うつかりドーピング防止のために各競技団体やス ポーツチームにおいて定期的なドーピング防止研修 会や競技会時にアウトリーチプログラムが実施され ている.1)しかしながら, 座学による世界アンチ・ ドーピング規程 (World Anti-Doping Code; CODE) を始めとするドーピング禁止物質や禁止方法に関す る知識の習得は科学の背景知識が十分ではないアス リートやその指導者にとっては難しく感じ，ドーピ ング防止に関して十分なノウハウが得られない場合

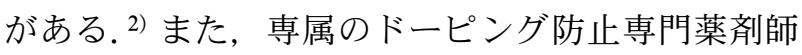
である日本アンチ・ドーピング機構（Japan AntiDoping Agency；JADA） 公認スポーツファーマシ スト(以下スポーツファーマシスト)を配置したり, 相談空口を設置したりしている競技団体においても

みどりや薬局（干427-0043 静岡県島田市中溝 4-8-10） e-mail: info@doping-guardian.com

本総説は, 日本薬学会第 141 年会シンポジウム S03 で 発表した内容を中心に記述したものである.
うっかりドーピング事例は起こっている. ${ }^{3)}$ 筆者は アスリートが主体的に取り組めるアンチ・ドーピン グ教育機会の提供及びドーピング防止のためのアス リートとスポーツファーマシストの関係づくりのた めにカードゲーム形式のアンチ・ドーピング教育 ツールであるうつかりドーピング防止カードゲーム 「ドーピングガーディアン」を開発した。 今回, ア ンチ・ドーピング教育カードゲームの開発の経緯と その活用事例について報告する.

1. アンチ・ドーピング教育活動の課題

アスリートを対象としたアンチ・ドーピング教育 は競技団体やスポーツチームでのアンチ・ドーピン グ研修会と競技会時やスポーツイベントなどでス ポーツファーマシストや競技関係者によるアウト リーチプログラムなどが主であるが，スポーツ ファーマシストとしてこれらのアンチ・ドーピング 活動を行う中で遭遇した課題を挙げる.

1-1. アンチ・ドーピング知識の難しさ 1 つ 目の課題はアンチ・ドーピング防止研修を講義形式 で実施する際に実際にアスリートやその指導者に提 供するドーピング禁止物質及びその禁止方法に関す る情報がアスリートにとって難解であることである. CODE における禁止表国際基準では作用機序によ 
り常時禁止されるドーピング禁止物質として S0-S5 の 6 カテゴリと禁止方法として M1-M3 の 3 カテゴ リ，競技会時に禁止されるドーピング禁止物質とし て S6-S9 の 4 カテゴリ，アーチェリーやビリヤー ドなどの特定競技のみベー夕遮断薬が禁止される P1 というカテゴリが存在する. ${ }^{4)}$ アスリートはこれ らの情報と対処法をドーピング防止研修という限ら れた時間のなかで身につける必要がある。しかしな がら，ドーピング禁止物質に関しては禁止表国際基 準に記載される特定の物質だけでなく, 類似の化学 構造や生物学的効果を有する物質が禁止されること などがあり，化学的な背景知識がそしいアスリート にとっては理解が難しく, 学びの機会においても基 本的に情報の取り入れに専念することとなり，学び の姿勢が受け身一方向になりがちである，その結 果，主体的なドーピング防止に関する学びに結びつ きづらくアスリート個人における具体的なドーピン グ防止対策が不十分となってしまう。

1-2. スポーツファーマシスト知名度の低さ 2 つ目の課題としてスポーツファーマシストの認 知度の低さが挙げられる。アスリートがドーピング 違反を避けるため，ドーピング禁止物質及び禁止方 法についてその対処が必要な際にアンチ・ドーピン グに関する専門的な見地からアドバイスができるの がスポーツファーマシストであるが，その認知度は 低い。そのためアンチ・ドーピングに関する相談案 件があったとしてもスポーツファーマシストへの相 談に結びつきづらい，全国にいるスポーツファーマ シストの中からアスリートにとって身近な地域のス ポーツファーマシストを検索するシステムも存在す るが，十分に活用されているとは言えない．結果と してスポーツファーマシストの知名度の低さはアス リート個人にとってはアンチ・ドーピングに関する 情報アクセス機会の低下を招いている.

1-3. スポーツファーマシスト活動機会の少なさ 3つ目の課題としてはスポーツファーマシスト全 体としての活動機会の少なさが挙げられる。2021 年 4 月現在, 登録されている JADA 公認スポーツ ファーマシスト認定者は全国に 11489 名いるがその 多くはドーピング相談，講演，競技会及びスポーツ イベントでの啓発活動の機会を得られていないこと が多い. 5) スポーツファーマシストがドーピング相 談などを受けるにはアスリートとのつながりが重要
な要素である、そのつながりをつくるためにはアン チ・ドーピング講演や啓発活動の機会が重要である が，一般のスポーツファーマシストの多くがこれら の活動の機会を得られないことからアスリートのつ ながりを作りづらい悪循環を生じさせている。 ま た，スポーツファーマシストがアンチ・ドーピング 教育を実施する際に活用できる教育プログラムや ツールも限られているため, 一般のスポーツファー マシストが自ら一歩踏夕出して活動をはじめるハー ドルが高くなっている.

2. アンチ・ドーピング教育カードゲームの開発 うっかりドーピング防止に向けて，難しいドーピ ング禁止物質及び規程を簡略化するとともにドーピ ング防止については「スポーツファーマシストへの 相談」という行為を定着させる教育手法を検討した 際に，アナログゲームを利用したアンチ・ドーピン グ教育ツールの開発を行うこととした。アンチ・ ドーピング研修だけでなく，スポーツイベントや自 宅や部活動単位でも気軽に使用できるように携帯性 の優れたカードゲームとして開発を行った．ゲーム 開発においては，アスリートが実際に行う日々の練 習や体調管理などトレーニング期間から競技会時及 び競技会後のドーピング検査までの一連の流れに関 し，アンチ・ドーピング規程に留意するとともに他 のプレイヤーと競いながら勝利を目指す過程を疑似 体験できるように設計した．また，ゲーム内におい ては個別のドーピング禁止物質には注目せず，日常 的に使用する可能性が高い医薬品及びサプリメント の剂型と投与経路に着目した。 そして，ゲームを有 利に進めるにあたつてのカギとなる要素として薬剤 師への相談という要素を入れ込んだ。こうして開発 したものがうっかりドーピング防止カードゲーム 「ドーピングガーディアン」である (Fig. 1).

\section{3. カードゲームの概要}

うつかりドーピング防止カードゲーム「ドーピン グガーディアン」は 67 枚のカードで構成され，2-5

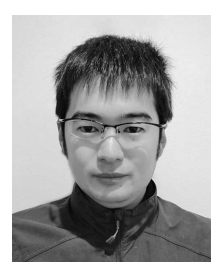

清水雅之
静岡県島田市出身. 2007 年第一薬科大 学薬学部卒業し, 2009 年静岡県立大学 院薬学研究科博士前期課程修了. 同年 より，みどりや薬局入社し 2015 年合同 会社みどりや薬局代表社員へ就任. 2018 年にうっかりドーピング防止カー ドゲーム「ドーピングガーディアン」 を開発し教育啓発活動を行う。 


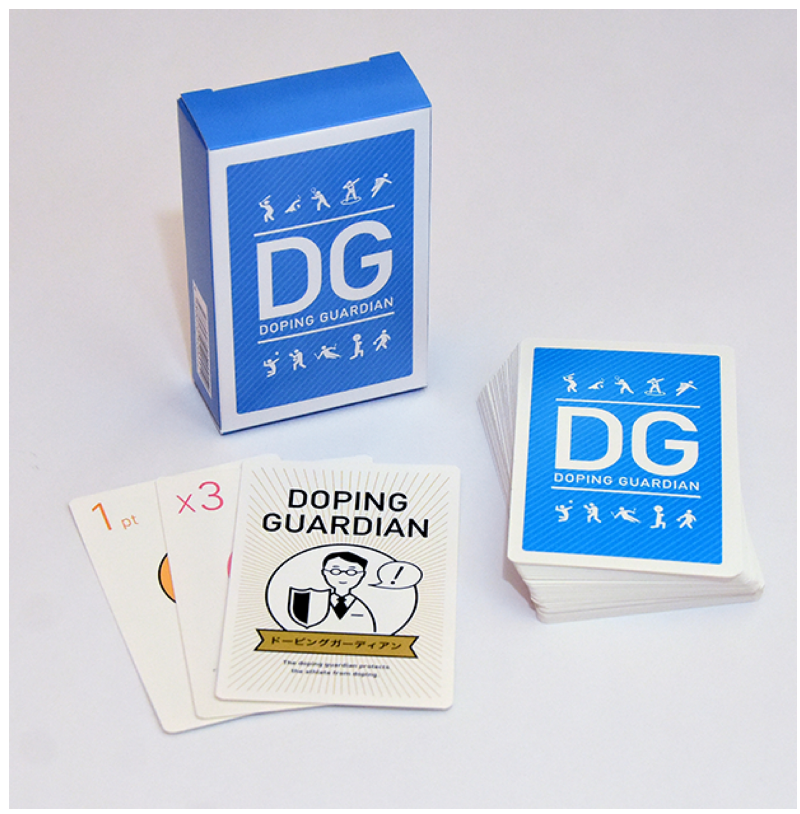

Fig. 1. Anti-doping Card Game "Doping Guardian" (Color figure can be accessed in the online version.)

名，1プレイ 15 分程度で遊ぶことができるカード ゲームである. プレイヤーはアスリートという設定 で，プレイヤーの目的はゲーム中で多くの得点を獲 得し，競技会で優勝することである．競技会までの 準備期間としてサプリメントを使用したり，病気や 怪我の際に医薬品を使用したりする，そのときに使 用した医薬品やサプリメントがゲーム内で設定され たドーピング禁止物質であった場合，勝敗を決定す る各プレイヤーの得点集計の終了後に行われるドー ピング検査フェーズにおいてドーピング禁止物質を 使用したプレイヤーは点数のいかんにかかわらず失 格となる，基本的な流れはまずはプレイヤーにラン ダムに手札となる 4 枚を配布し，次にドーピング禁 止物質と設定されたことになるカードをドーピング 禁止物質カードとして伏せ札として場に 5 枚配置す る. 残りのカードは山札としてプレイヤーはターン ごとに山札からカードを引くことでゲームが進行す る. プレイヤーはターンごとに山札からカードを 1 枚引いたのちに，手札から任意のカードを自分の場 に 1 枚出すことにより点数を獲得したり，病気の治 療を行ったりする.

3-1. カードの種類 67 枚あるカードは 5 種類 「トレーニングカード」「サプリメントカード」「病 気カード」「薬カード」「ドーピングガーディアン」 に分類できそれぞれに特性があるので概要を述べる
(Fig. 2).

3-1-1. トレーニングカードトレーニング カードはゲーム勝敗の基礎となる得点を獲得するこ とができる．トレーニングカードには「柔軟体操」 「ランニング」「スイミング」「筋トレ」の 4 種類が ありそれぞれ 1 点又は 2 点を獲得することができ る. 本ゲーム中で勝利条件に必要な点数を直接獲得 できるものはトレーニングカードだけである，後述 のサプリメントカードでトレーニングカードの点数 を増やすこともできるがそれもあくまでトレーニン グカードの強化という目的である，本ゲーム中でも スポーツの世界と同じく, 勝利の基本的な条件は着 実なトレーニングの積み重ねというメッセージでも ある。

3-1-2. サプリメントカードサプリメント カードは既に使用したトレーニングカードの得点を 倍化できるカードである。 サプリメントカードはそ の剂形により「錠剂」「カプセル」「ゼリー」「粉末」 の 4 種類がそれぞれ 3 枚ずつある. 使用したトレー ニングカード 1 枚につきサプリメントカードを 1 枚 だけ使用できトレーニングカードの得点を $2-3$ 倍に 増やすことができる。

3-1-3. 病気カード 病気カードが自分の手札 に加わってしまった場合は, かならず場に出すこと になり強制的に減点される。病気カードには「アレ ルギー」「腹痛」「発熱」「ケガ」の 4 種類があり, それぞれ 3 点から 6 点の減点となる. 病気の機会は 自分で選ぶことができず，病気カードを引いてし まつた場合トレーニングの機会なども奪われてしま うということである.

3-1-4. 薬カード＼cjkstart薬カードは自分の場に出さ れている病気カードに使用することでその減点を無 効化することができる。薬カードもサプリメント カードと同様にその剂形により「錠剤」「カプセル」 「塗り薬」「貼り薬」の 4 種類がそれぞれ 3 枚ずつあ る. 剂形によるカードの種類に内服だけではなく, 「塗り薬」と「貼り薬」の外用薬も採用した理由に はうっかりドーピングの原因に外用薬は禁止物質の 対象外とアスリートが誤認している例事例も少なく ないため, ゲーム中にも外用薬の使用を意識させる ことを目的としている．使用する薬カードはその病 気カードの種類にかかわらず，減点を無効化するこ とができる. 


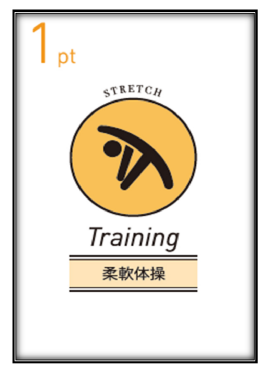

Training Card

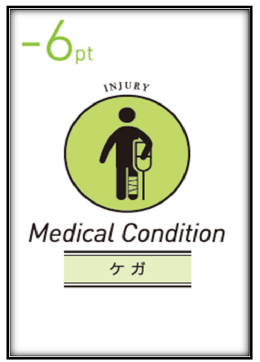

Medical Condition Card

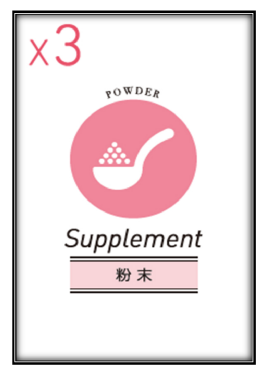

Supplement Card

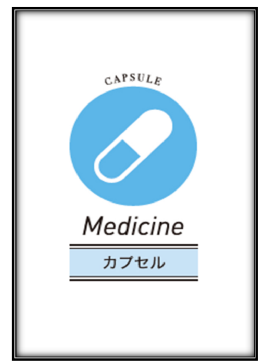

Medicine Card

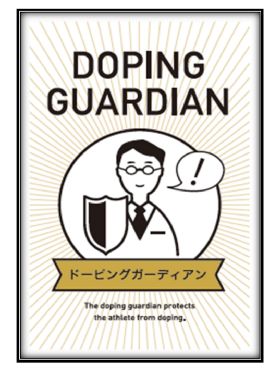

Doping Guardian

Fig. 2. "Doping Guardian" Cards

(Color figure can be accessed in the online version.)

3-1-5. ドーピングガーディアンカードドー ピング禁止物質について相談ができる薬剤師カード で，サプリメントカード及び薬カードはプレイヤー が任意に使用することができるが，ゲーム終了時に 行われるドーピング検查というフェーズでドーピン グ禁止物質カードとして伏せ札に設定されていたサ プリメントカード及び薬カードと同じカードを使用 してしまった場合，ドーピング違反として失格と なってしまう。しかし，ドーピングガーディアン カードをゲーム中に使用することで伏せられている ドーピング禁止物質カード 5 枚のうち 2 枚を自分だ けみることができる．本カードをゲーム途中で活用 することにより，禁止物質の可能性のあるサプリメ ントカード及び薬カードをさけてトレーニングの効 果を高めたり，病気の治療を行ったりすることがで きる.

4. アンチ・ドーピング教育にカードゲーム

アンチ・ドーピング教育にカードゲームを取り入 れることで，アスリートはうつかりドーピングが起 こってしまう過程とその防ぎ方をゲームの中で疑似 体験することができる，その結果，アスリートにお いてはゲームを行うことによって，どのような行為 がドーピング行為となってしまい，またどのような
行動をとることによってうつかりドーピングを防ぐ ことができるのかを学ぶことができる。これはドー ピング禁止物質や禁止方法を知識として身につける というものだけではなく，ノウハウとしてのアン チ・ドーピングを学ぶことができる.

また，カードゲームを始めとするアナログゲーム はコミュニケーションを取りながら実施する必要が あり，複数人で行うことによりアンチ・ドーピング に関する知識の共有と認識の共通化が図れる．アス リートだけでなくコーチやトレーナーなどのサポー トスタッフと一緒に本ゲームをプレイすることによ り各人の知識や認識を知ることとなり，アンチ・ ドーピングに関するコミュニケーションが円滑に進 むことが期待される.

そして，本ゲームにおいてうつかりドーピング防 止の重要な要素にドーピングガーディアンカードと して薬剤師カードを導入した。これは本ゲームをプ レイすることにより，うつかりドーピングを防ぐた めにはいかに医薬品やサプリメントを摂取する前に スポーツファーマシストを始めとする薬剤師に相談 することが重要であることを身に付けてもらうとと もに，ゲームを通じてスポーツファーマシストの知 名度向上を目指すものである. 
知名度向上とともにスポーツファーマシストの活 動機会の増加も期待できる. スポーツファーマシス トが行うアンチ・ドーピング研修会の多くはひとり で実施するものが多いがそれでは市中の一般スポー ッファーマシストがアスリートと直に触れ合うには 活動の機会が少なくなってしまう。アンチ・ドーピ ング研修会においては 4-5 名のグループに分かれて ドーピングガーディアンを体験してもらい，その際 にグループごとにスポーツファーマシストを配置し て解説やアドバイスを行うことでより実践的な学び の機会となる.

つまり，ドーピングガーディアンを利用したアン チ・ドーピング研修会に複数人のスポーツファーマ シストが参加することでアンチ・ドーピング教育の 質の向上とともに一度に複数人のスポーツファーマ シストが動員できることとなりこれまで活動の機会 を得ることが難しかったスポーツファーマシストに 対しても活動の門戸が広がる，また個人での教育啓 発活動を始めようとしているスポーツファーマシス トにとっても，競技団体や教育機関へ向けて教育用 カードゲーム体験という教育プログラムの提供を活 動のきっかけとすることも期待できる.

\section{5. アンチ・ドーピング活動事例}

これからドーピングガーディアンを活用したス ポーツファーマシスト活動事例を紹介する. なお, 紹介する活動事例の中にはアスリートを対象とした アンチ・ドーピング教育啓発目的以外にも医薬品適 正使用や薬学教育なども含まれる.

5-1. アスリート向け研修会＼cjkstart実際にドーピン グ検査が実施される競技団及びプロスポーツチーム から，ジュニア世代に向けて実施しているもので, 例えば研修時間が 90 分の時間構成とした場合，冒 頭の 30 分程度で基本的なドーピング規則及び禁止 物質に関する内容を一通り学び，そこで学んだ内容 を踏まえて 5-6名の小グループに分かれてドーピン グガーディアンをプレイする. 1 回目はゲームルー ル以外，スポーツファーマシストが特にアドバイス を行わずにプレイする. 1 回目のゲーム終了後に各 グループにファシリテーターとして配置しているス ポーツファーマシストが解説を行う。それ以降もス ポーツファーマシストが専門的見地からアドバイス や解説を行いながらゲームをプレイする．ゲーム体 験を 40 分ほど行ったのちに改めてゲーム中で体験
したことを踏まえた解説を事後講義として 20 分実 施する.このプログラムによりアスリートは冒頭に 学んだ基礎的な知識をそのままゲーム体験で実践で きる．ゲーム中ではうつかりドーピング違反の疑似 体験ができるとともに事後講義にて反省点や注意点 を自分事として再確認ができる.

これまでもプロスポーツチーム，競技団体，高等 学校運動部，小学生スポーツチームなどでそれぞれ の競技レベルにあわせた教育内容で講義とゲーム体 験をあわせたアンチ・ドーピング研修を実施してい る.

5-2. 地域活動での活用地域で行われるス ポーツ大会や健康イベントでは市民アスリートに向 けてアンチ・ドーピング啓発と同時に医薬品やサプ リメントの適正使用啓発としてドーピングガーディ アンを活用し実施している.

ドーピングガーディアンのルールはアンチ・ドー ピング規則を基礎に設計されているが，禁止物質と されている部分の解釈をその人にとって摂取が望ま しくない物質と置き換えることで医薬品やサプリメ ントの飲み合わせや持病との係わりなどに啓発内容 を広げることができる。薬剤師が地域イベントでコ ミュニケーションを取りながら，啓発活動を行うこ とでその地域にとってより顔の見える薬刘師として の認識を高めることができる，薬局薬剂師において は調剂報酬や薬機法の中で地域の健康増進に係る活 動への参加が推奨されており，地域でのドーピング ガーディアン活用はアンチ・ドーピング教育啓発を きっかけにした健康増進活動としても活用できる.

5-3. スポーツファーマシスト向け研修会 ス ポーツファーマシスト向け研修会においてはスポー ツファーマシストのスキルアップを目的として実施 している. 研修プログラムとしてはスポーツファー マシストやスポーツ医療専門職による講義に加えて ドーピングガーディアン体験会を行う。スキルアッ プを主目的として実施している研修会ではあるが， 副次的にスポーツファーマシストやスポーツ医療に 関連する多職種間の連携促進も目的としているため 講師や参加者にはスポーツファーマシストだけでは なくスポーツ栄養士や理学療法士なども参加してい る. その背景としてアンチ・ドーピング活動やアス リートからのドーピング相談を応需する際に他者に 意見を求めたくても，横のつながりがなく不安に感 
じるスポーツファーマシストが少なくないというこ とだ. ドーピングガーディアン体験を含むスポーツ ファーマシスト向け研修会ではゲーム体験を通じた 交流により参加者同士が横のつながりを作り易い. その結果, 研修会終了後もスポーツファーマシスト のつながりが生まれ地域のアンチ・ドーピング教育 啓発活動に発展するコミュニティ形成のきつかけに もなつた。

5-4. 薬学教育の現場での活用薬学教育の現 場では主に 2 つに分けてドーピングガーディアンを 活用した教育啓発活動を実施している．1つ目は小 中高生に向けた薬物乱用防止を含む薬学講座での活 用である。薬物乱用や医薬品適正使用に関する教育 を行う際にスポーツにおけるドーピングを例に薬物 の及ぼす身体への影響や自分の将来への影響をゲー ムで疑似体験をしながら進めることができる。また ゲームを通じて，地域や医療の中で薬剤師がごのよ うな役割を果たしているのか示しながら薬剤師の仕 事紹介に活用している.

2 つ目は薬学部学生に向けた教育現場での活用で ある、アンチ・ドーピングに関する知識とスポーツ ファーマシストの仕事内容について学ぶ際にドーピ ングガーディアンを活用する．主な例を挙げると薬 局や病院での実務実習の中で現場の薬剤師がスポー ツファーマシスト業務を紹介する際ドーピングガー ディアン体験を行っている.

\section{6. 競技レベルにあった教育プログラムの必要性}

2021 年に改訂された CODE ではドーピング違反 が意図的ではない証明をアスリート自身が示すこと が必須化されるとともに意図的な違反や重大な違反 に対してより厳しい制裁が科されることとなった。

つまり，疾患の治療やサプリメント摂取が原因であ る意図的ではないうつかりドーピングに関してもア スリート自身が意図的ではない証明を示すために日 常的に医薬品やサプリメントを摂取する現場におい てアンチ・ドーピングの専門家であるスポーツ ファーマシストとのつながりがより重要となってく る.

その一方でこれまではアンチ・ドーピングにおい て区別されていなかった競技レベルによるカテゴリ 分けが行われるようになり，16 歳未満のアスリー ト，18 歳未満でも一定の競技レベルに達していな いアスリートや責任能力が十分でないアスリートを
「要保護者」とし，これまで国内や国際レベルの競 技者に含まれたことがない，国際的な競技会で国の 代表をしたことがない，登録検査対象者リストや検 査対象者リストに含まれていても居場所情報を提出 したことがないなどいずれもしたことがないアス リートを「レクリエーション競技者」として通常の ドーピング違反と比べて柔軟な制裁が科されること となった。

悪質性が低いドーピング違反の制裁の軽減などを 考慮すると, 要保護者やレクリエーション競技者に おいてはこれまでのアンチ・ドーピングだけを目的 としたサポートや教育よりも日常的な疾患の治療に おける医薬品適正使用や女性アスリートへの月経調 整，安全で効果的なサプリメント摂取などの薬学的 サポートの重要性が増すことが考えられる．これら の需要にスポーツファーマシストが対応するために はアンチ・ドーピングに限らない幅広いアスリート サポートの知識とともにアスリートとの関係性を醸 成していく必要がある.

さらに 2021 年の CODE 改訂では教育に関する国 際基準 (international standard for education; ISE) も新たに策定された。 ${ }^{6}$ その中でもアスリートに とってアンチ・ドーピングに関する最初の経験は ドーピング検査などではなく，教育を通じて行われ るべきであると示されるとともに，CODE と同様 に教育を施す対象として広範な競技者やサポートス タッフだけでなく，その他のターゲットグループと して子供や若者世代，教育関係者及びメディアなど が教育プロセスの一環として考慮されるべき存在と して挙げられている.

しかしながら，これまでのところ教育ツールなど を用いた標準的なアンチ・ドーピング教育プログラ ムというものは少ない. ドーピングガーディアンは カードゲームであり，一定のルールの下に実施され るものなので標準化し易く, 2018 年の発表以降薬 剂師を中心に日本全国のスポーツ現場及び教育現場 などで活用されている.

ISE が目指すべきアンチ・ドーピングを実現する ためにも今後は全国で実施されているアンチ・ドー ピング教育についての実績や実施後にどの程度行動 変容に影響を及ぼしたかなどの教育効果に関する評 価も重要である. ドーピングガーディアンに関して も全国で実施してきたスポーツイベントやアスリー 
ト向け研修会での事例を示していきたい.

\section{まとめ}

アスリートにとってアンチ・ドーピング教育とい うのはフェアプレーの精神だけでなく, うっかり ドーピング防止のためにも必要な知識とノウハウで あるが，その煩雑さなどによりどうしても受動的な 学びになりがちである. カードゲームという手法で アンチ・ドーピング教育の敷居を下げると同時に医 薬品適正使用と関連づけることにより，教育の対象 をこれまでの一部のドーピング検査対象者となる恐 れのあるアスリートだけでなく，ジュニア世代から 一般市民に向けても教育啓発を行うことができる. また，カードゲームなどの体験型の教育は主体的な 学びとともにアスリートとスポーツファーマシスト を始め体験者同士をつなげる役割が期待できる.

2021 年現在, スポーツファーマシスト認定取得 者は全国に約 1 万人おり，その中には認定取得して から全く活動をしたことがないスポーツファーマシ ストも少なくない. 個々のスポーツファーマシスト が多職種を含めた横のつながりを構築し, 相互に連 携した活動を行うことでより充実したアンチ・ドー ピング活動ができると考える.

利益相反＼cjkstart開示すべき利益相反はない.

\section{REFERENCES}

1) Japan Anti-Doping Agency. "Education and enlightenment.": 〈https://www.playtruejapan. org/activity/education.html $\rangle$, cited 21 July, 2021.

2) World Anti-Doping Agency. "World AntiDoping Code 2021.": 〈https://www.wadaama.org / sites / default / files / resources / files / 2021_wada_code.pdf $\rangle$, cited 21 July, 2021.

3) Sports Pharmacist. "What is a sports pharmacist?"':〈https://www.sp.playtruejapan.org /about/index.html〉, cited 21 July, 2021.

4) World Anti-Doping Agency. "Prohibited List Documents.”: 〈https://www.wada-ama.org/ sites / default / files / resources / files / 2021list en.pdf $\rangle$, cited 21 July, 2021.

5) Sports Pharmacist. "Certification system outline.”: 〈https://www.sp.playtruejapan.org/ acquire/index.html , cited 21 July, 2021.

6) World Anti-Doping Agency. "International Standard for Education.": 〈https://www. wada-ama.org/sites/default/files/resources/ files/international_standard_ise_2021.pdf $>$, cited 21 July, 2021. 